\title{
The Digital Economy: From the Management of the Human Capital Development to Ensure Economic Security
}

\author{
Evgeniya K. Karpunina ${ }^{1, *}$, Yuri A. Salikov², Natalia I. Kuzmenko ${ }^{3}$, Natalia P. Nazarchuk ${ }^{4}$, Olga N. \\ Gorbunova $^{1}$ \\ ${ }^{1}$ Institut of Economics, management and service, Tambov State University named after G.R. \\ Derzhavin, Internationalnaya str., 33, Tambov, Russia \\ ${ }^{2}$ Department of Economic security and financial monitoring, Voronezh State University of \\ Engineering Technology, Prospect of Revolution, 19, Voronezh, Russia \\ ${ }^{3}$ Department of Philosophy, Economics and social Sciences and Humanities, Voronezh State \\ Pedagogical University, Lenin street, 86, Voronezh, Russia \\ ${ }^{4}$ Department of Economics, Tambov State Technical University, Berry str., 137, Tambov, Russia \\ *Corresponding author
}

Keywords: Human Capital, Digital Economy, Economic Security, Human Capital Development.

Abstract: Currently, the main trend in the development of the global world order is digitalization, which is associated with the infiltration of digital technologies in all spheres of society. There are transformations in production processes, systems of exchange and sale of products, the nature of work. Individuals develop new preferences, aspirations and mechanisms to achieve them. On the surface there are absolute advantages of the digital environment, which are felt by individuals in their everyday life, the company, the state. Meanwhile, the threats to security from the digital economy are forgotten. The purpose of this article is to study the relationship between the processes of management of human capital development and economic security in the formation of the digital economy ecosystem. The development of human capital has both a positive and a negative impact on the economic security of the state.

\section{Introduction}

The new digital age and the fourth industrial revolution have had an unprecedented impact on people's lives and the way they work. Technological progress necessitates the development of human resources as a key factor of production and a source of innovation in the digital age. The funds invested in a person, his education, training and retraining, in maintaining comfortable working conditions and creating effective motivation systems, form the basis for the progressive development of national economies and their safe existence in the new conditions.

At the same time, scientists note that human capital in the conditions of digitalization changes the forms of employment and the nature of production relations. As a result of continuous improvement of professional skills of employees and their desire for constant self-development, competition for 
talents in the labor market increases many times. Talent selection requires speed and flexibility to quickly identify the need for specialists for a specific job, find professionals with the necessary skills and assemble a team capable of completing the task in a short time. Thus, the BBC describes the current state of the economy in the capacious term "GigEconomy". This is a relatively new but extremely important business term, which is defined as "the modern model of the economy in which the labor market is dominated by freelancing and project work - as opposed to permanent employment." The traditional concept of "career path" gradually loses its importance and gives way to temporary employment, when professional skills are valued.

In addition, the productivity of the employee is no longer dependent on its location: according to CB Insights, in the US every third employee has moved to the ranks of freelancers, by 2020 their share will grow to $40 \%$ of the total number of employees. $51 \%$ of top managers surveyed by CB Insights expect to use the services of temporary contractors over the next 3-5 years. Such trends cause a whole range of new threats to the economic security of States and dictate certain requirements for its maintenance systems. At present, effective tools for managing human capital development are required, which will be implemented by companies and the public administration system and will ensure the safe functioning of the economic system.

\section{Materials and Methods.}

At the present stage of human development, the need for economic security has increased in many countries, as in the conditions of digitalization (when the main activity of economic agents is associated with the use of digital technologies, the implementation of operations with various kinds of data, being in the global digital space) there is not only a number of opportunities for future development, but also a lot of negative phenomena that threaten financial stability not only for individual enterprises, but also for the whole state [1].

The need for economic security is associated with the elimination of potential and real threats and challenges that threaten the socio-economic stability of the state and individual spheres of activity and can undermine their economic and production potential. The most important global challenge is widespread digitalization $[2,3]$.

Significant transformations in production methods, the transition to a new technological order, characteristic of the digital economy, cause a change in the role and place of human capital in the system of socio-economic relations $[4,5]$ :

I. Availability of intellectual assets that are used to improve economic efficiency. Currently, the most attractive for investors are companies with a significant amount of human resources. A striking example here are representatives of the Internet economy, such as Facebook, Uber, Airbnb, which, in fact, without having physical assets, are digital platforms and are ahead of many industrial giants in their capitalization [6].

II. Increasing the importance of data in economic activity. Today, the digital economy is based on a complex ecosystem of interconnected information and communication technologies, based on the processing of "big data" provided by complex analytical tools. One of the trends in data management is "cloud" technologies, which are man-generated and allow data management in a flexible, scalable way. Companies that use cloud technologies in their activities reduce the cost of creating and maintaining their own digital infrastructure. The use of digital technologies contributes to increased productivity [7].

III. The network becomes the main organizational structure. This form of organization is more adapted to the rapid changes in the market, which affects their efficiency. The competitiveness of modern economies is based on the network interaction of companies that produce, distribute and use joint resources. Its interactive nature implies that innovative ideas are generated at all stages of 
the production cycle. There are numerous horizontal links, specialists of various professions and qualifications are involved in the innovation process. Relationships with suppliers, consumers, competitors, research organizations.

IV. In its production activities, the modern employee fully uses Internet resources (websites, digital platforms, messengers), and data exchange is becoming global. The degree of access to the global data network, markets and technologies determines the efficiency and competitiveness of individual workers and economic systems [8].

$\mathrm{V}$. The basis of the management process is self-organization based on the use of flexible and effective forms, such as crowdsourcing, crowdfunding and "share economy" [9].

\section{Results and Discussion.}

Let us compare the main trends in the development of human capital in the digital environment, as well as new opportunities and threats to the economic security of the state (table 1).

Table 1.Influence of Trends in Human Capital Development on the State of Economic Security in the Digital Environment

\begin{tabular}{|c|c|c|}
\hline Trends & Economic opportunity & Threats to economic security \\
\hline $\begin{array}{l}\text { The Formation } \\
\text { GigEconomy }\end{array}$ & $\begin{array}{l}\checkmark \\
\text { by companies to perform the most } \\
\text { by thent of the best specialists } \\
\text { complex production tasks } \\
\checkmark \quad \text { the productivity of the worker, } \\
\text { does not depend on its location } \\
\checkmark \quad \text { cost reduction companies on the } \\
\text { workers }\end{array}$ & $\begin{array}{l}\text { the emergence of an unaccounted part of the } \\
\text { country's GDP due to the spread of freelancing } \\
\text { high degree of dependence of labor results on } \\
\text { "figures", information security threats } \\
\text { "leakage" of highly skilled workers } \\
\text { unemployment ineffective workers } \\
\text { loss of national identity } \\
\text { increasing the vulnerability of the economic } \\
\text { system of the state } \\
\text { the growth of the shadow economy }\end{array}$ \\
\hline $\begin{array}{l}\text { The } \\
\text { emergence of } \\
\text { new } \\
\text { professions } \\
\text { and } \\
\text { competencies }\end{array}$ & $\begin{array}{l}\checkmark \text { growth of production capacities of } \\
\text { companies } \\
\checkmark \quad \text { increase of technological } \\
\text { effectiveness of the production process } \\
\checkmark \quad \text { the emergence of new business } \\
\text { models and tools to promote products and } \\
\text { services } \\
\checkmark \quad \text { continuous process of } \\
\text { improvement of knowledge and skills of } \\
\text { employees, growth of professionalism and } \\
\text { adaptability to changing conditions } \\
\checkmark \quad \text { increasing the speed of response } \\
\text { of specialists }\end{array}$ & $\begin{array}{l}\text { rising unemployment due to the withering } \\
\text { away of several traditional professions } \\
\text { income level } \\
\text { increasing differentiation of population by } \\
>\quad \text { information inequality } \\
\text { systems }\end{array}$ \\
\hline $\begin{array}{l}\text { Automation } \\
\text { and } \\
\text { digitalization } \\
\text { of the labor } \\
\text { process }\end{array}$ & $\begin{array}{l}\checkmark \text { acceleration of production } \\
\text { operations } \\
\checkmark \text { raising the level of analytic and } \\
\text { prognosticate management processes } \\
\checkmark \text { increase of accuracy of } \\
\text { calculations } \\
\checkmark \text { increasing the efficiency of } \\
\text { business processes }\end{array}$ & $\begin{array}{l}>\text { data leakage } \\
\text { cyber-espionage and the growing } \\
\text { criminalization of the economy } \\
>\quad \text { information processing and analysis } \\
\text { systems failure due to the use of malicious software } \\
>\quad \text { cyber attacks and undermining business } \\
\text { reputation of the companies } \\
>\quad \text { fraud on the Internet } \\
>\quad \text { information inequality } \\
>\quad \text { uncontrolled use of the Internet }\end{array}$ \\
\hline
\end{tabular}


In the global Risks Report 2018, the WEF's global risks report, cybercrime and data theft are ranked third and fourth in importance [10]. The intensive exchange and the use of large streams of data reduces the degree of confidentiality of the used information and contribute to the creation of a number of digital threats. The emergence of a systemic failure in the digital economy will compromise the existence of individual companies, banks and organizations.

There is also concern about the ability of the digital economy to create sufficient high-quality jobs and to ensure that the benefits of growth are widely shared between and within countries. ILO estimates that there are about 200 million unemployed in 2017, while the global unemployment rate is expected to remain stable in 2018, as the labor force expands in line with increasing digital trends, demographic changes and participation, the global unemployment rate could rise even further [11]. Taking into account the above, we believe that the criteria for assessing the level of economic security of the state in the digital environment should take into account two groups of parameters: traditional-industrial and intellectual-technological (table 2).

Table 2. Criteria-Based Assessment of the Level of Economic Security of the State in the Digital Environment

\begin{tabular}{|l|l|}
\hline \multicolumn{1}{|c|}{ Traditional-industrial parameters } & \multicolumn{1}{|c|}{ Intellectual and technological parameters } \\
\hline $\begin{array}{l}\text { The state resource potential and opportunities for } \\
\text { its development }\end{array}$ & Level of human capital development \\
\hline $\begin{array}{l}\text { The ability of the economy to function in the } \\
\text { mode of expanded reproduction and } \\
\text { competitiveness of the economy }\end{array}$ & $\begin{array}{l}\text { State of scientific, technical and innovative } \\
\text { potential of the country }\end{array}$ \\
\hline The stability of the financial system & $\begin{array}{l}\text { Level of investment in education, training and } \\
\text { retraining }\end{array}$ \\
\hline Balance of foreign economic policy & Information technology activity of companies \\
\hline $\begin{array}{l}\text { The effectiveness of state management of the } \\
\text { economy }\end{array}$ & Effectiveness of social policy \\
\hline $\begin{array}{l}\text { The standard of living of the population, as well } \\
\text { as the level of poverty, unemployment and } \\
\text { property differentiation. }\end{array}$ & Level of information security of the economy \\
\hline
\end{tabular}

\section{Conclusions}

For the sustainable development of the state in the conditions of digitalization, it is necessary to implement a two-level system of economic security based on the management of human capital development.

I level - the level of the company: 1) Implementation of talent strategies based on the use of talent platforms as the main means of organizing the workforce. 2) Implementation of digital HR management technologies based on artificial intelligence and machine learning - such as GetLinks or Arya - in order to reduce costs and attract the best candidates. 3) Implementation of highpotential employee identification (HiPo) technology based on infographics - identification of future leaders, their retention and adequate development, succession planning and management of the "bench" of management staff. 4) Formation of team work skills and effective development of teams on the basis of evaluation of teams of managers, identifying the sources of their productivity and important destructive factors; consulting in the field of improving the effectiveness of team interaction. 5) Use of IT-technology of corporate wellness-services implementation as a tool of struggle for intellectual resource and retention of qualified personnel. The economic meaning of the wellness programs is to increase the overall level of health, physical and mental staff to reduce the 
cost of additional health insurance and losses associated with the absence of staff due to illness. 6) Introduction of gamification methods for training and human resource management. For example, the Track2Win service uses the game mechanics of car racing to gamify work in the office. Performing tasks forces the employee to move the race car to the finish line. Performance statistics of each employee is displayed on the overall race scale and is visible to all employees. This stimulates healthy competition. 7) Implementation of corporate information security systems and increase of information literacy of employees.

II level-level of the state.

The state policy includes 4 interconnected blocks (Fig. 1).

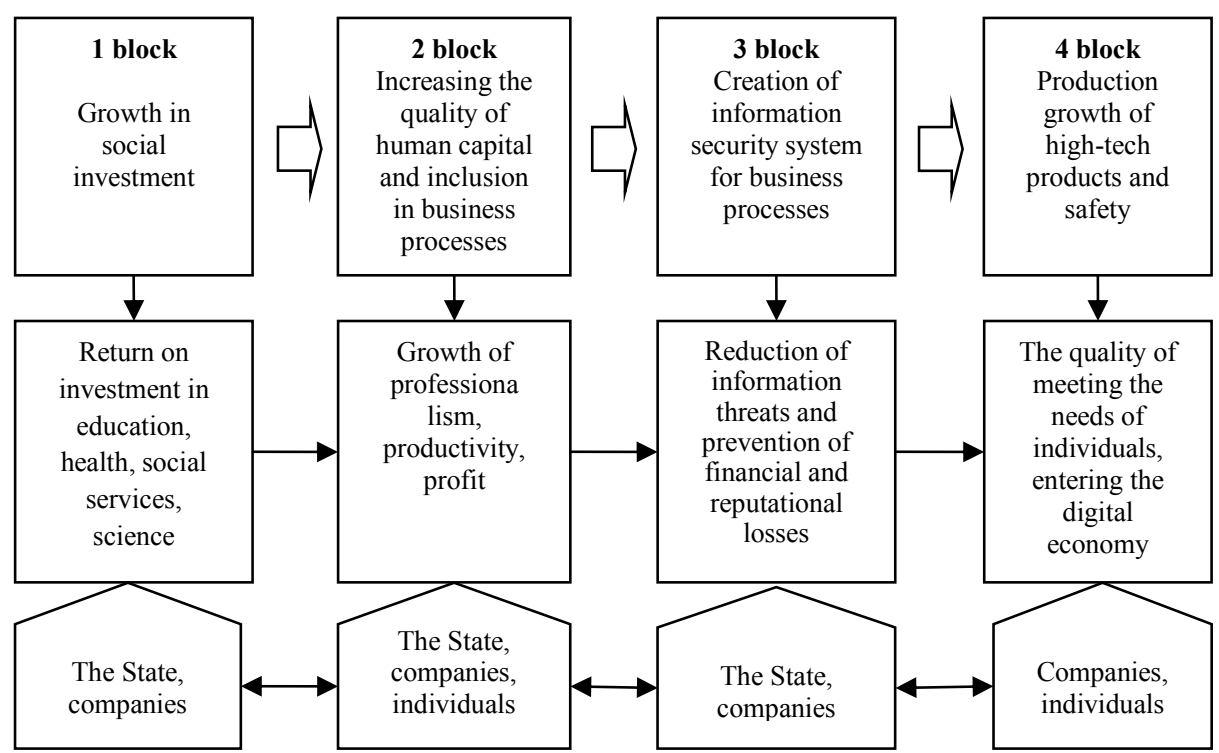

Figure 1. Concept of State Policy to Ensure Economic Security in the Digital Environment

\section{References}

[1] V. Senchagov, Russian economic security. General course: the textbook [C]. Moscow: Business, 2005.

[2] E. Damiani, L. Uden, W. Trisnawaty, The future of E-learning: E-learning ecosystem. Proceedings of the Inaugural IEEE Digital Ecosystems and Technologies Conference (IEEE DEST), ISBN: 1-4244-0467-3, 21-23 February 2007, Cairns, Australia, 113-117.

[3] E. Karpunina, S. Moiseev, O. Gorbunova, Resistance is not hopeless...regarding the policy of countering information threats of economic security. Proceedings of the 33nd International Business Information Management Association (IBIMA), ISBN: 978-0-9998551-2-6, 10-11 April 2019. Granada, Spain.

[4] D. Bell, The Coming of Post-Industrial Society [M]. New York: Basic Books, 1973.

[5] P. Drucker, The Age of Discontinuity [M]. New York: HarperCollins, 1969.

[6] E. Popov, K. Semyachkov, V. Simonova, Simulation conditions for the development of network structures [J]. Vestnik Urfu, 2016, 3, Vol. 15: 324-341.

[7] I. Ilyin, A. Anisiforov, The Use of cloud technologies in the construction of cluster information systems [J]. Economics and management, 2012, 7 (81): 22-27. 
[8] H. Gruber, Innovation, skills and investment: A digital industrial policy for Europe [J]. Journal of Industrial and Business Economics, 2017, Vol. 44, Iss. 3: 327-342.

[9] E. Karpunina, E. Yurina, S. Samoylova, Digital Economy and Business Structures: A New Meaning of Interaction or Threat to Economic Security? Proceedings of the 32nd International Business Information Management Association (IBIMA), ISBN: 978-0-9998551-1-9, 15-16 November 2018, Seville, Spain.

[10] World Economic Forum, The Global Risks. Report 2018. 13th Edition [OL]. https://www.weforum.org/reports/the-global-risks-report-2018

[11] ILOSTAT 2016, ILO modelled estimates [OL]. https://www.ilo.org/ilostat/ 